Sādhanā Vol. 39, Part 3, June 2014, pp. 549-571. (C) Indian Academy of Sciences

\title{
Study of liquid fuel transport in a small carburetted engine in the context of cold-start $\mathrm{HC}$ emission control
}

\author{
SUMIT TEWARI, T N C ANAND, M P NISHIKANT \\ and R V RAVIKRISHNA*
}

Department of Mechanical Engineering, Indian Institute of Science, Bangalore 560 012, India

e-mail: ravikris@mecheng.iisc.ernet.in

MS received 13 December 2012; revised 24 January 2014; accepted 24 January 2014

\begin{abstract}
In the present study, a detailed visualization of the transport of fuel film has been performed in a small carburetted engine with a transparent manifold at the exit of the carburettor. The presence of fuel film is observed significantly on the lower half of the manifold at idling, while at load conditions, the film is found to be distributed all throughout the manifold walls. Quantitative measurement of the fuel film in a specially-designed manifold of square cross section has also been performed using the planar laser-induced fluorescence (PLIF) technique. The measured fuel film thickness is observed to be of the order of $1 \mathrm{~mm}$ at idling, and in the range of 0.1 to $0.4 \mathrm{~mm}$ over the range of load and speed studied. These engine studies are complemented by experiments conducted in a carburettor rig to study the state of the fuel exiting the carburettor. Laser-based Particle/Droplet Image Analysis (PDIA) technique is used to identify fuel droplets and ligaments and estimate droplet diameters. At a throttle position corresponding to idling, the fuel exiting the carburettor is found to consist of very fine droplets of size less than $15 \mu \mathrm{m}$ and large fuel ligaments associated with length scales of the order of $500 \mu \mathrm{m}$ and higher. For a constant pressure difference across the carburettor, the fuel consists of droplets with an SMD of the order of $30 \mu \mathrm{m}$. Also, the effect of liquid fuel film on the cold start HC emissions is studied. Based on the understanding obtained from these studies, strategies such as manifold heating and varying carburettor main jet nozzle diameter are implemented. These are observed to reduce emissions under both idling and varying load conditions.
\end{abstract}

Keywords. Carburettor; small engines; cold-start HC emissions; fuel film visualization; PLIF; PDIA; droplet sizing; backlit visualization.

*For correspondence 


\section{Introduction}

There is a renewed interest in small carburetted engines both from the point of view of Small off-road engines (SORE) emissions in USA, and extensive use of two-wheelers in Europe and Asian countries. Particularly in Asian countries where a majority of two-wheelers are powered by engines of capacity $150 \mathrm{cc}$ or less, carburettors have remained the fuel mixture preparation device of choice due to their much lower cost, simplicity and relative insensitivity to fuel quality which makes them ideal for use in a range of conditions. Also, for low power applications such as power tools, and for small off-road engines such as those in lawn-mowers and snowmobiles, carburettors are an ideal choice. Hence, there is a pressing need to develop better emission control strategies for carburetted engines. Often, emission standards are met by exhaust after treatment using catalytic converters. However, very few studies have focussed on the fuel transport processes in the intake manifold which has a major effect on mixture preparation and hence emission formation. Some important studies among these include early studies by Harrington \& Bolt (1970) who performed a numerical simulation of an air-bled type carburetted system, and Oya (1971) who studied the two-phase flow through emulsion tubes similar to that in carburettor and has given some empirical equations for the pressure drop at the confluence of the air and fuel flow for different values of void-fraction corresponding to different flow regimes. More recently, Li \& Collings (1999) proposed a semi-empirical model of fuel transport in the intake manifold and demonstrated its application to transient conditions. Arias \& Shedd (2004) developed a one-dimensional model which could predict the mixture enrichment and pressure drop under pulsating flow conditions. Itano (1996) studied the flow at the exit of three carburettors under steady state conditions and obtained qualitative film thicknesses by measuring the electric resistance of the fuel film, though droplet sizes were not measured. Very few studies have been done to understand the state of the fuel exiting the carburettor. In a work done by Finlay et al (1984), the size of droplets at the exit of the throttle plate of a carburettor was measured. It was observed that the fuel film formation at the manifold walls created problems in this measurement. This study also brought out the challenges involved in droplet sizing due to fuel droplet deposition on the visualization window. The poor transient response of carburetted engines has been attributed to film formation in previous studies. Tanaka \& Durbin (1977) investigated the transient response of a single cylinder SI carbureted engine, and concluded that part of the fuel which flows in as a liquid film exhibits a first order delay. Hamid \& Walter (1985), by taking a similar approach as that of Tanaka \& Durbin (1977), performed a numerical study to estimate the amount of the fuel film at different pipe length to diameter ratios and also to estimate the time delay caused by the fuel film.

Studies in literature have also purported to observe the effect of these liquid fuel films on HC emissions from carburetted engines. Experiments by Hasson \& Flint (1989) utilised a wall film separator to remove the film and has reported a reduction in $\mathrm{HC}$ emissions when wall films were removed. Felton et al. (1995) compared an electronic fuel injection system with an air-assisted fuel injection system and observed that while the extent of wall films was very different; the level of unburned hydrocarbons was similar, thus indicating that it is not necessary that liquid fuel film deposition is the cause of unburned HC emissions. Salazar \& Ghandhi (2006) studied a pre-vaporized fuelling system and a carbureted system. From a statistical point of view, there is no difference in $\mathrm{HC}$ emissions between both fuel systems. Therefore, this suggests that the liquid fuel does not significantly affect the $\mathrm{HC}$ emissions. They also indicated that day-to-day variability is a significant issue.

To summarize, wall films have been observed to affect $\mathrm{HC}$ emissions to a large extent in some studies, whereas others have not found this to be the case. As mentioned earlier, one study has 
attributed changes in $\mathrm{HC}$ emissions to day-to-day variability rather than to the film itself. Thus, it is observed from literature that there are contradictory observations regarding the effect of wall films on HC emissions. The present work attempts to resolve this ambiguity.

In the present work, a detailed study of liquid fuel film transport inside the inlet manifold of a small carburetted engine has been done at cold-start conditions. This includes a qualitative visualization of fuel film transport inside the manifold, a quantitative measurement of fuel film thickness, and a study of the state of the fuel exiting the carburettor. Experiments have also been conducted to understand cold start hydrocarbon emissions and their relation with the fuel film observed in the inlet manifold at cold start conditions. The following sections describe the engine setup, the optical diagnostic techniques utilised, discussion of the results and conclusions from the study.

\section{Experimental set-up}

\subsection{Engine with instrumentation}

Figure 1 shows the block diagram of the integrated setup utilized for the experiments. The engine used for experiments is a small $110 \mathrm{cc}$ single-cylinder, four-stroke, carburetted engine whose specifications are given in table 1 . The inlet system of the engine consists of the air filter, inlet pipe, carburettor, inlet manifold (diameter $=19.5 \mathrm{~mm}$ ) and inlet valve. The carburettor used is a standard slider valve carburettor. The engine is coupled to a water-cooled eddy-current dynamometer by a universal coupling. The dynamometer is controlled by a controller with a LabVIEW interface. The measurement sensors incorporated on the setup include a Kistler piezoelectric in-cylinder pressure sensor, crank angle encoder, piezoresistive absolute pressure sensors in the manifold, a MRU Delta 1600-L exhaust gas analyser and a Hall-Effect spark timing sensor. The signals from the pressure sensors, crank angle encoder and spark timing sensor were

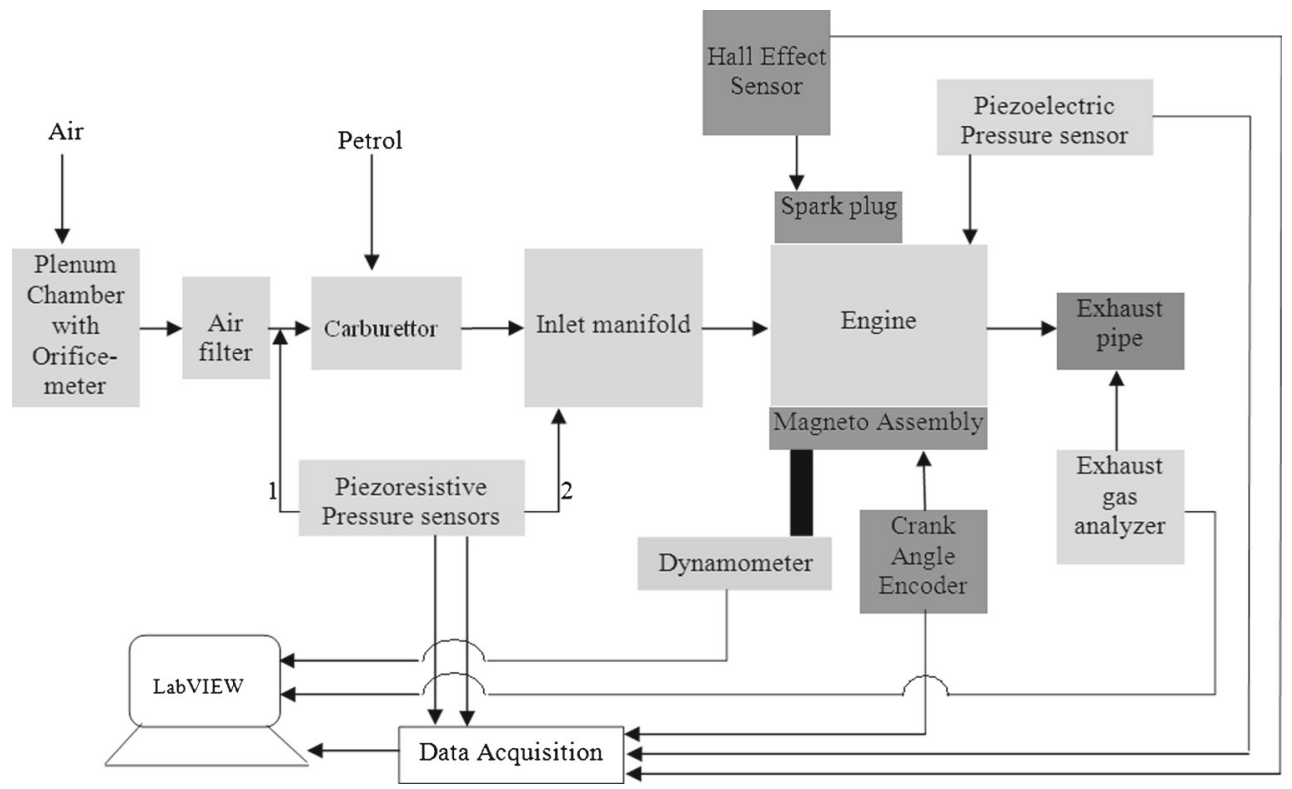

Figure 1. Integrated set-up used for experiment. 
Table 1. Details of the engine used.

\begin{tabular}{ll}
\hline Engine Type & $\begin{array}{l}\text { Single cylinder, air-cooled 4-stroke } \\
\text { carburetted, SOHC engine }\end{array}$ \\
\hline Bore & $51 \mathrm{~mm}$ \\
Stroke & $53.5 \mathrm{~mm}$ \\
Swept Volume & $109.3 \mathrm{c.c}$. \\
Rated Power & $6.04 \mathrm{KW}$ at $7250 \mathrm{rpm}$ \\
Rated Torque & $8.46 \mathrm{Nm}$ at $5500 \mathrm{rpm}$ \\
Transmission & 4 -speed constant mesh gearbox \\
Carburettor & Slider valve type \\
Engine Idling Speed & $1400 \pm 100$ RPM \\
Compression Ratio & 9.2 \\
Fuel & Gasoline \\
IVO & $340^{\circ}$ \\
EVC & $370^{\circ}$ \\
IVC & $565^{\circ}$ \\
Inlet manifold diameter & $19.5 \mathrm{~mm}$ \\
\hline
\end{tabular}

acquired using a National Instruments data acquisition system with LabVIEW interface. The exhaust gas analyser output was connected to computer with the help of a RS 232 port for continuous measurement.

Figure 2 shows a schematic of the carburettor used in the experiments. The first image shows the three main circuits of a carburettor; Idling jet circuit, main jet circuit and choke circuit. The figure also shows the flow volumes of the main jet circuit. The flow in the main jet circuit is regulated by the needle which is attached to the bottom of the slide valve. This tapered main jet needle moves inside the emulsion tube and varies the cross section available for fluid flow. The petrol enters the emulsion tube through the main jet nozzle at the bottom which is dipped inside the petrol sump. The emulsion tube has eight side orifices through which air enters. The idling jet circuit is similar to the main jet circuit. It has an emulsion tube with the idling jet at the bottom and air holes on the sides. However, the idling circuit does not have a needle to control the flow of petrol based on throttle. The air for the main jet and idling jet circuit is bled off just upstream of the carburettor through two passages which can be seen in the figure. The absolute pressure sensors are installed before and after the carburettor and used for studying the pressure difference across the carburettor and also for calibrating the in-cylinder piezoelectric pressure sensor. The carburettor and piezo-resistive pressure sensors are shown in figure 3.

\subsection{Optical diagnostics}

To study the transport of the liquid fuel film moving inside the inlet manifold and to study the state of the charge exiting the carburettor, various visualization experiments were performed in the inlet manifold, and at the carburettor exit. The techniques and the setups used for these are discussed below.

2.2a Backlit imaging setup: Backlit images of the flow in the intake manifold were obtained with backlighting, to study the fuelling and the flow of liquid film. To obtain optical access, an attempt was made to prepare a transparent manifold while retaining the size and shape of the original manifold. As shown in figure 4a, the geometry of the actual manifold is complex and 

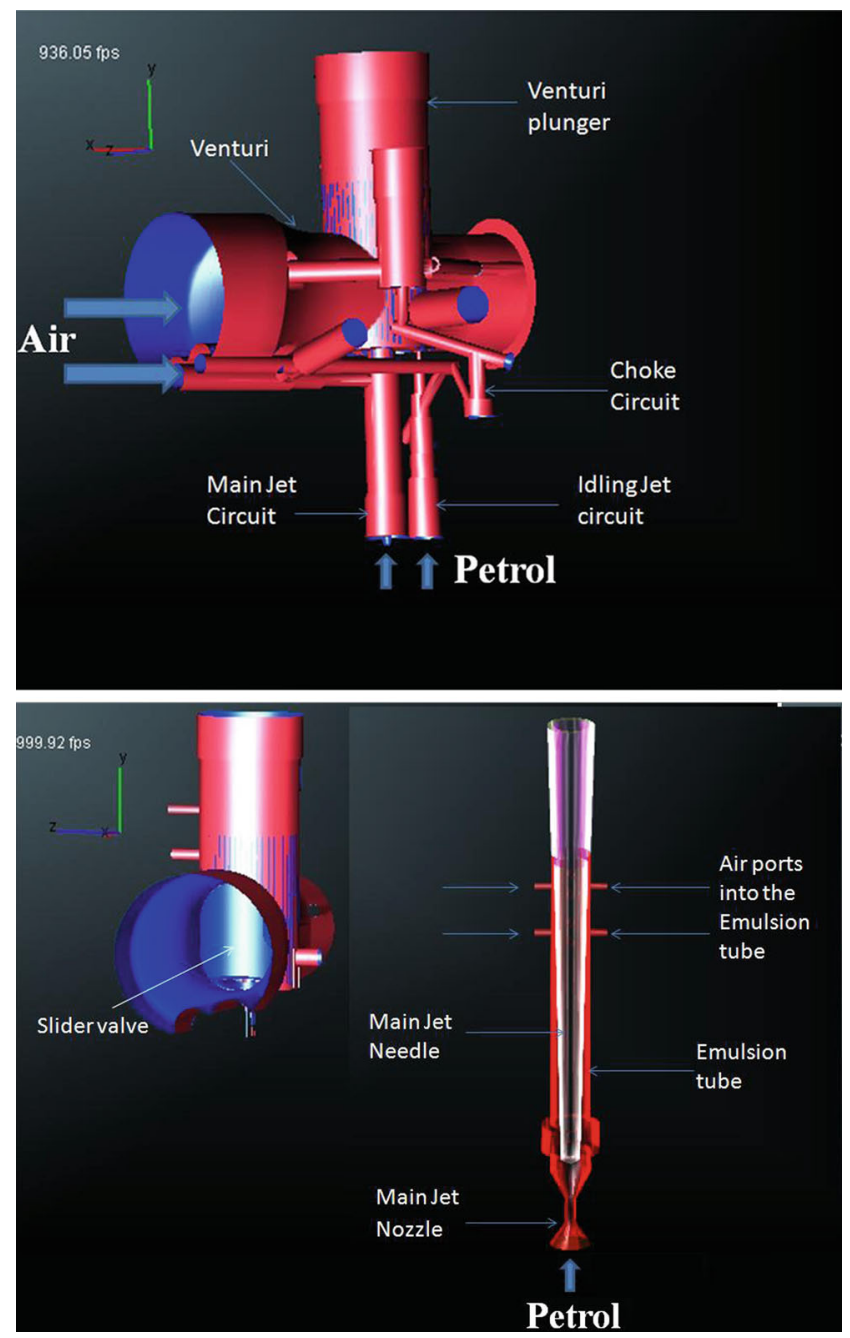

Figure 2. CAD drawing of the slider valve carburettor used in the experiment.

inclined in two planes, and due to its small dimensions, it was not possible to fabricate an identical transparent section while maintaining the desired transparency and optical characteristics as well. Hence, a portion of it, $46 \mathrm{~mm}$ in length, which corresponds to the straight part, was manufactured in quartz and the metal portion retained for the rest of the other manifold. Figure $4 \mathrm{~b}$ shows a photograph of the actual manifold with optical section. A Bosch 90W, 12V D.C. incandescent lamp was utilized to provide backlighting in the optical manifold described. A frosted glass plate was utilised to get a uniform distribution of light on the back of the manifold, and images were acquired using a Photron 500 frames per second high speed camera with a Nikon $50 \mathrm{~mm}$ focal length lens. For prolonging the cold start condition, a neoprene high-temperature resistant gasket was used to avoid heat transfer from the engine side. 


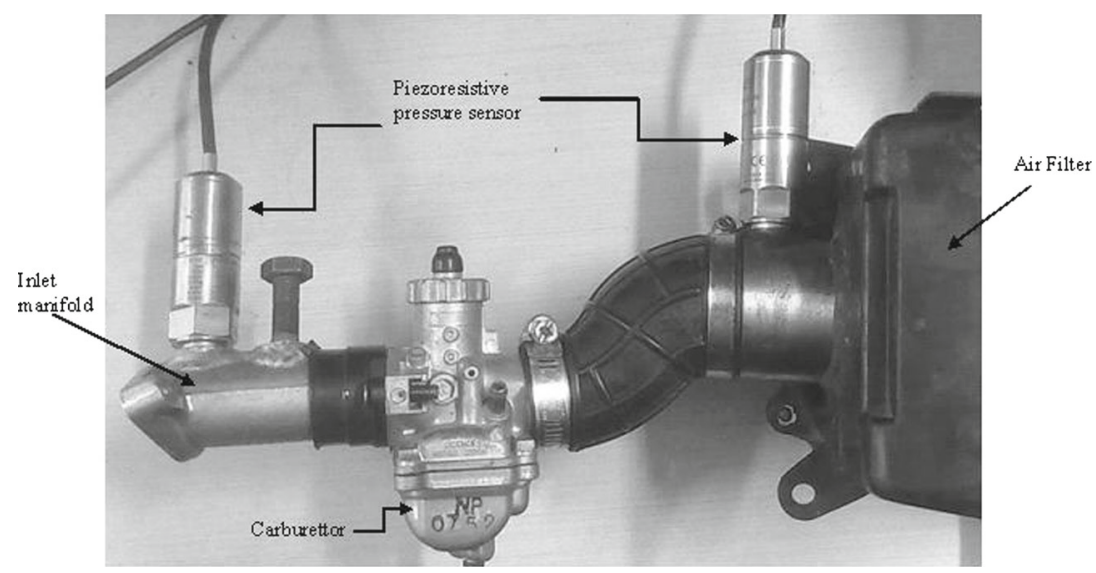

Figure 3. Piezoresistive pressure sensor installation before and after the carburettor.
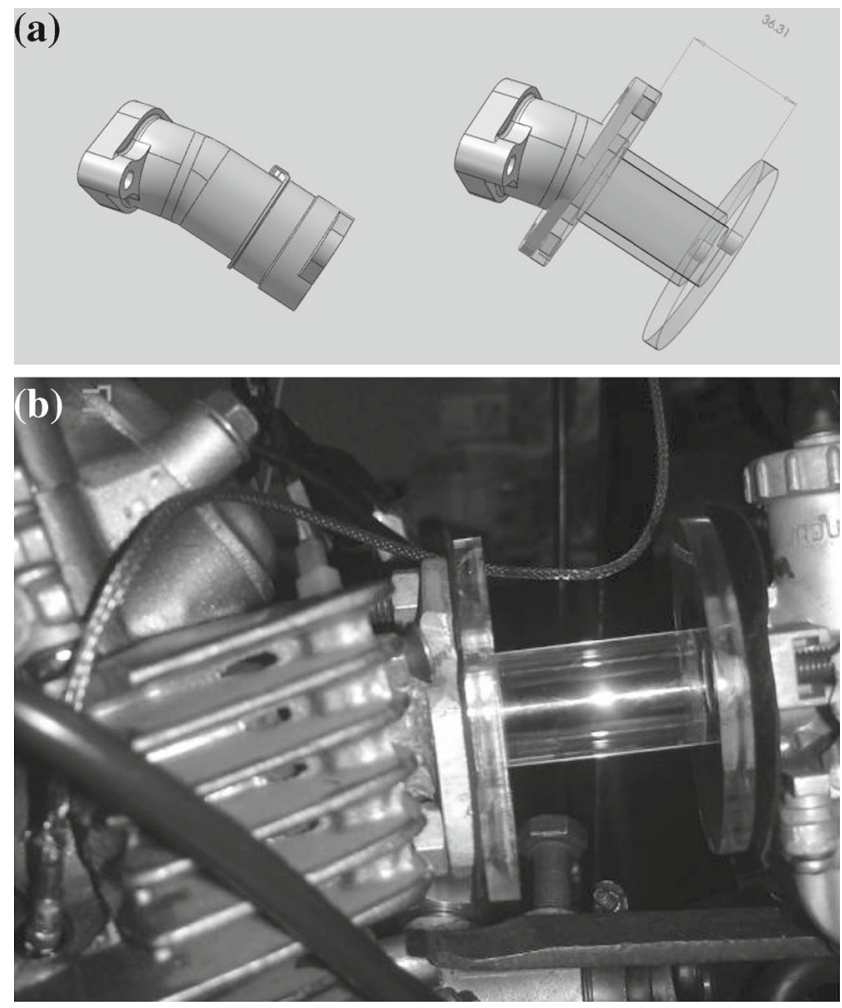

Figure 4. (a) CAD model of actual inlet manifold (left) and the manifold with optical section (right) (b) Photograph of actual manifold with the optical section (carburettor is on the right and engine head is on the left of the pictures). 
2.2b Planar laser induced fluorescence (PLIF) setup: For quantitative measurement of the film thickness, an extensive set of experiments was done using the Planar Laser Induced Fluorescence (PLIF) technique. The experiments were performed under both idling and load conditions. For fluorescence, Rhodamine $6 \mathrm{G}$ dissolved in ethanol was mixed with petrol in the ratio of 1:10:200 [Rhodamine(g): Ethanol(1):Petrol(1)]. Since it is not possible to visualize the film in a manifold of circular cross section due to distortion of light, a manifold with an insert (19.5 mm $\times 19.5 \mathrm{~mm} \times 30 \mathrm{~mm}$ ) having a square cross section, was used for these experiments. Transition inserts were used to change the geometry from a circular to square and square to circular cross section at the carburettor and engine sides respectively, as shown in figure 5. A continuous diode laser $(532 \mathrm{~nm})$ was used in conjunction with a cylindrical lens to form a $1 \mathrm{~mm}$ thin laser sheet. A high-speed Photron camera with a band pass filter of centre wavelength $600 \mathrm{~nm}$, and a FWHM of $80 \mathrm{~nm}$ was used to capture the fluorescence images. The camera was phase-locked with the engine by means of a controller circuit to enable capture of images at any particular crank angle. In the present study, phase-locked images of the fluorescence were captured at various crank angle degrees after TDC and the background image was subtracted from these images. The thickness measurements were made based on image data, i.e., counting the number of pixels in the wall-normal direction that are associated with the fluorescence signal After subtracting the background (which includes the camera noise), the presence of a pixel intensity greater than a predefined threshold value was taken as an indication of the presence of a film. A calibration

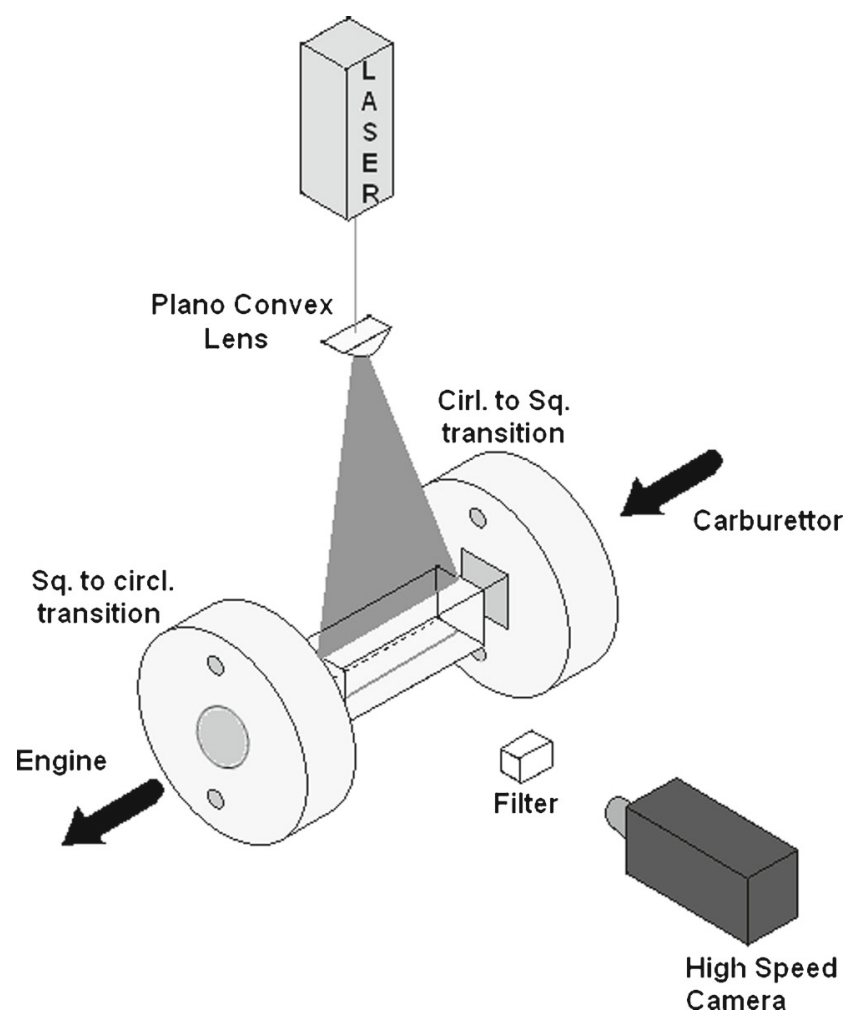

Figure 5. Schematic of the PLIF setup. 
target was imaged prior to the experiment to obtain an accurate estimate of the spatial resolution. At the given magnification, each pixel represents $100 \mu \mathrm{m}$, and hence the resolution is of that order. Hence, the error in the measurement of film thickness is $\pm 100 \mu \mathrm{m}$.

2.2c Droplet sizing using PDIA: Studying the state of the charge exiting the carburettor is a challenge due to the fuel film formed in the inlet manifold and the circular cross section of the manifold. Hence, for performing droplet sizing measurements, a setup was prepared where the carburettor exit is kept open to the atmosphere, while the carburettor inlet, the petrol sump and the fuel surge are all pressurized, maintaining the pressure difference across the carburettor to the values measured in the running engine. The pressure measurement at the carburettor inlet was done with a piezoresistive pressure sensor and for the real time analysis of the pressure a LabVIEW interface is used. A schematic of the setup used for the drop sizing is shown in figure 6. For drop sizing, the Particle/Droplet Image Analysis (PDIA) technique is used, where the fuel droplets are illuminated with a frequency-doubled pulsed Nd:YAG laser beam of wavelength $532 \mathrm{~nm}$ in combination with a fluorescent diffuser. A 12-bit LaVision CCD camera was synchronized with the laser, and used to acquire images. A long distance microscope was used

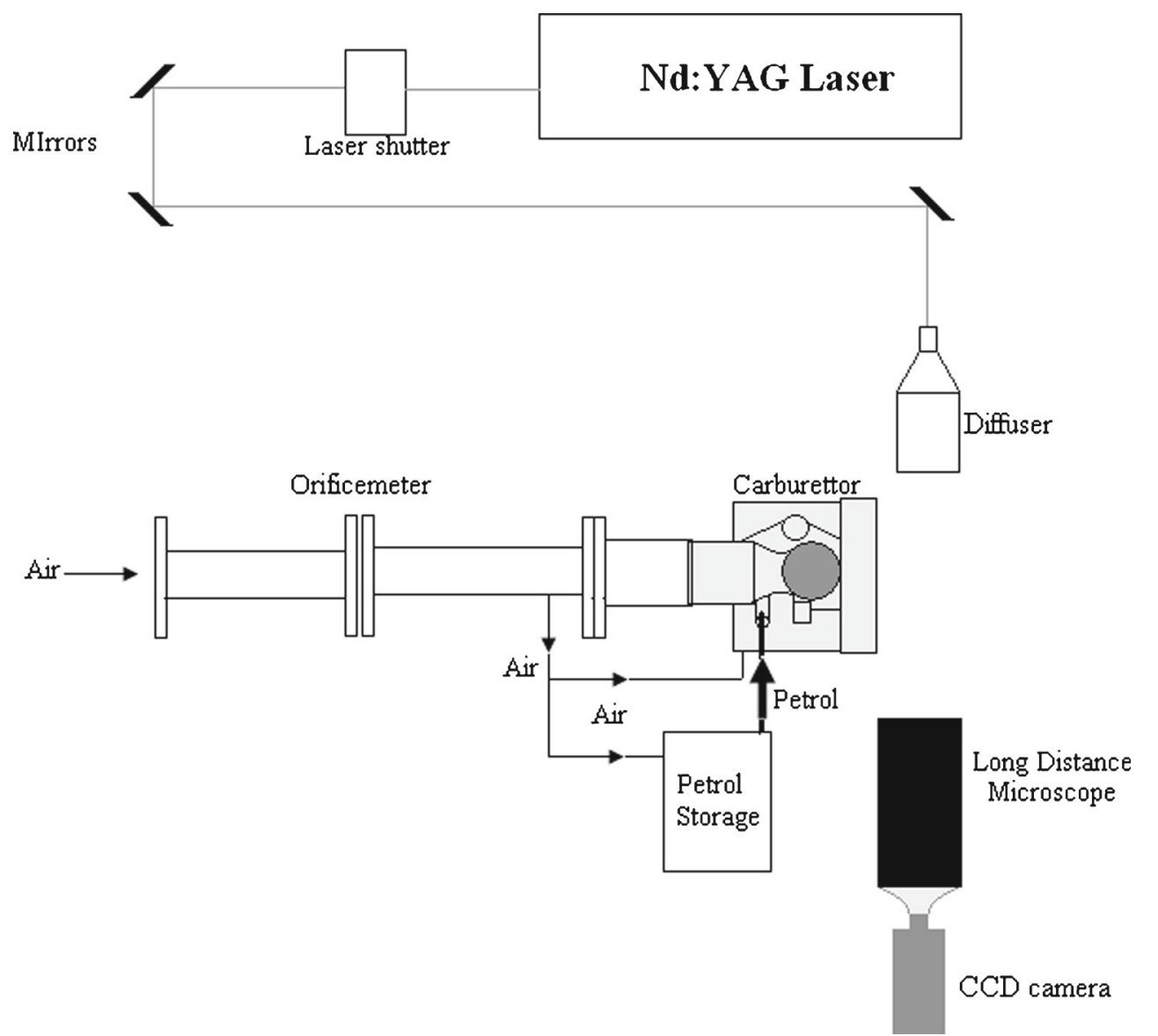

Figure 6. Schematic of the optics used for doing carburettor drop sizing using PDIA technique. 

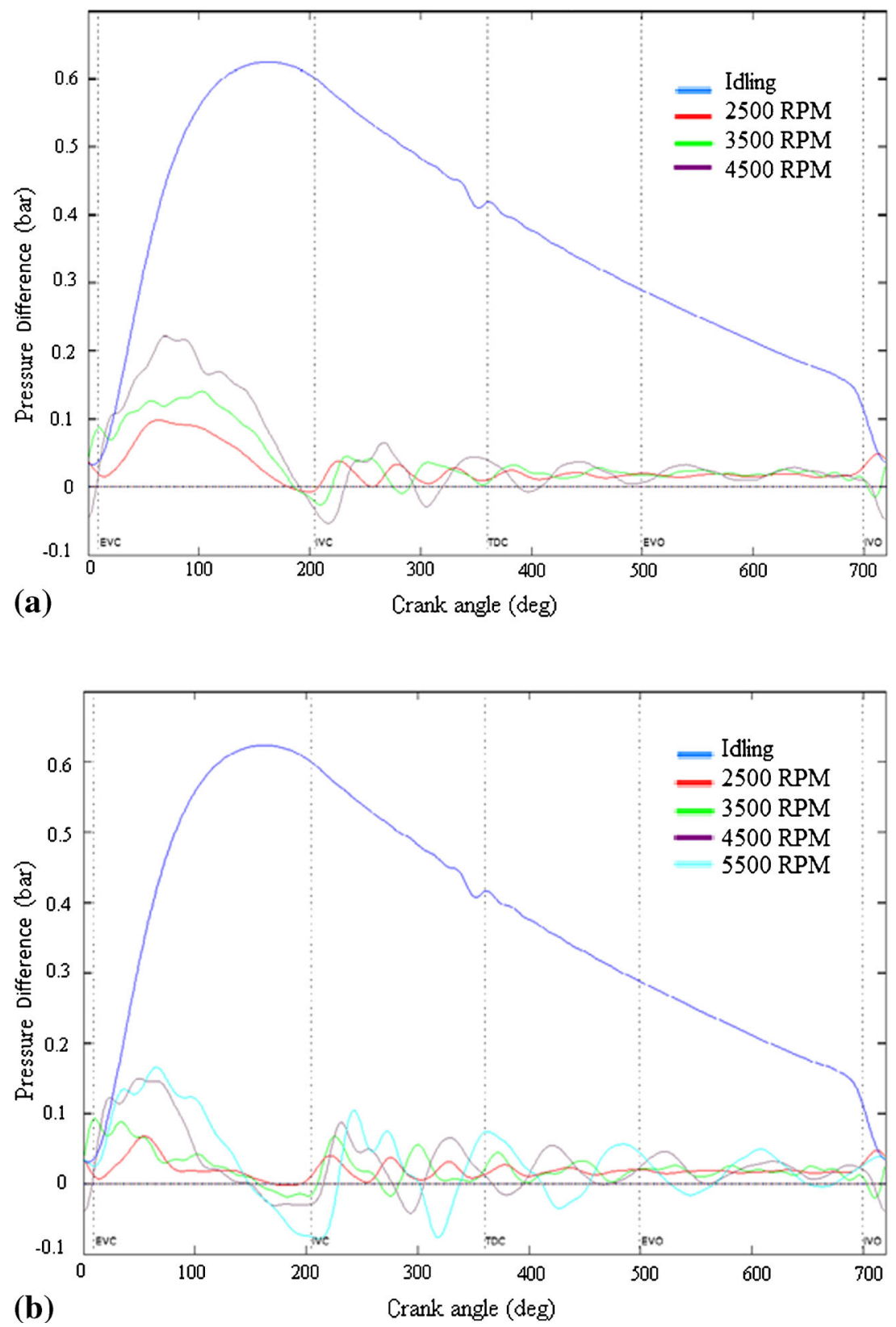

Figure 7. Pressure difference across the carburettor for different RPM cases compared to idling. (a) Halfthrottle, (b) Full-throttle.

in conjunction with the camera to zoom in and measure droplet sizes. The DaVis software was used to acquire images which were processed using the LaVision Particle Master Shadow module. The software rejects the particles which are out of focus based on the relative intensity of the particles. Thus, only particles within the depth of focus are processed and sized. 


\section{Results and discussion}

In a single cylinder engine, the behaviour of the flow across the carburettor is highly transient and shows large variations with crank angle compared to a multi-cylinder engine, where the pressure across the carburettor remains comparatively steady. As shown in figure 7 under idling conditions, the pressure difference (defined here as upstream value minus downstream value) across the carburettor, remains always positive. Under loading conditions, the pressure difference across the carburettor attains negative values at various times in the cycle, which shows a possibility of back flow across the carburettor. The data show damped oscillations with a peak at the start of the intake stroke. The amplitude of the pressure difference across the carburettor (both at positive and negative side) increases as the speed increases at a fixed throttle position, i.e., as the speed increases, the charge going inside the engine cylinder increases, but the amount of back flow also increases. Most of the back flow (due to a negative pressure difference) is recorded around and after the intake valve closing (IVC), though for high speed cases, a negative pressure difference is also observed at IVO, in the valve overlap region. As the throttle opening

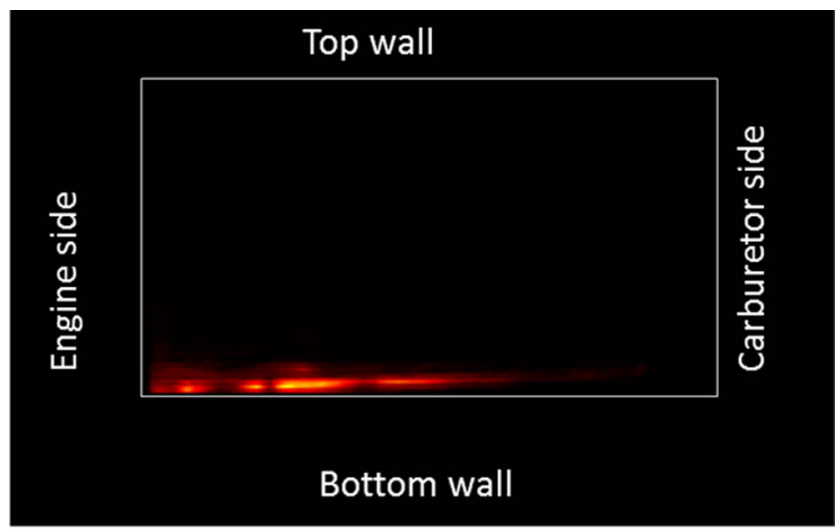

(a)

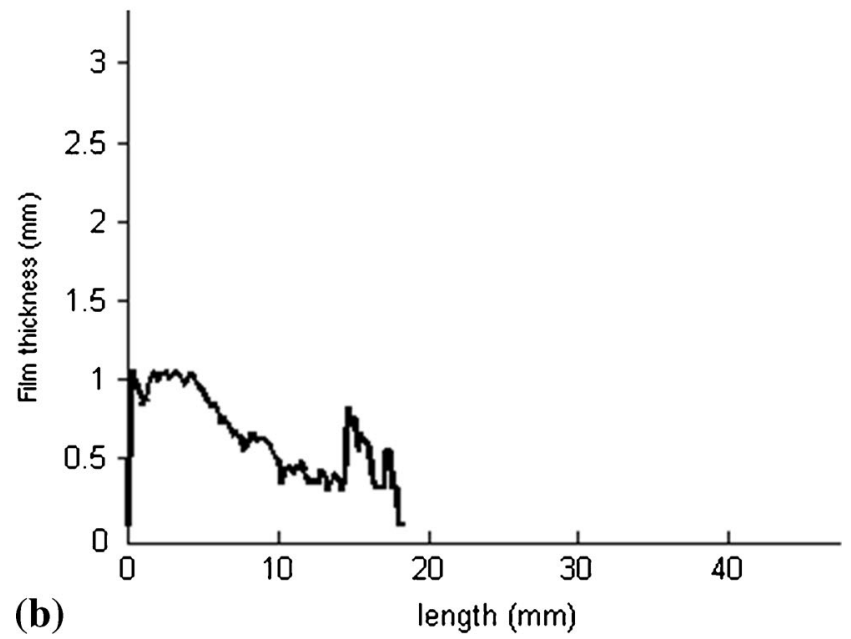

Figure 8. Fuel film thickness measurement. (a) False colour PLIF image, (b) Processed data. 

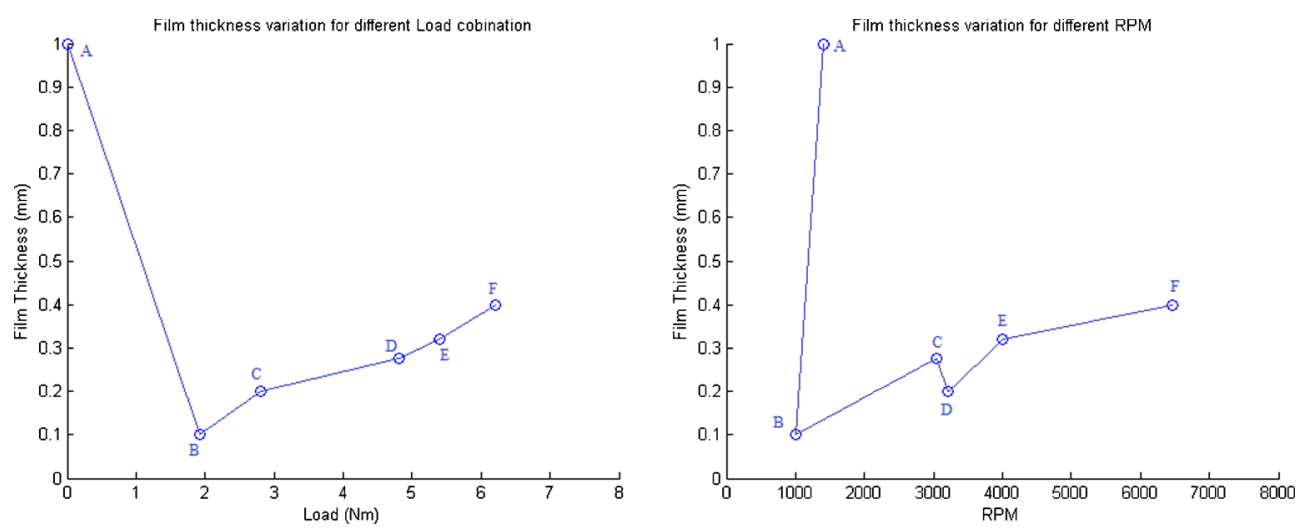

Figure 9. Fuel film thickness variation for different load and engine speed combinations. The error in the measurement of film thickness is $\pm 100 \mu \mathrm{m}$.

increases, the amplitude of the pressure difference across the carburettor decreases though the span of negative pressure difference increases to a small extent.

\subsection{Study of fuel film transport}

Initially, visualization of the fuel film transport inside the inlet manifold was performed by backlighting technique. A portion of the manifold is made transparent, and the visualization was performed at the exit of the carburettor under cold start conditions at idling and three throttle positions. The film formed from the carburettor end does not evaporate at cold start conditions in the manifold, and thus a constant presence of film moving towards the engine is observed at the bottom of the manifold in the case of idling. There is hardly any film which is observed on the upper half of the manifold for the length of the manifold analysed. The film appears to emerge from the sides of the slide valve of the carburettor. Due to circular cross-section of the pipe, after a small distance the fuel film starts converging towards the bottom of the manifold. The thickness of the film cannot be measured in this experiment, however, due to circular nature of the pipe. As the throttle is opened, the fuel film which lies at the bottom of the manifold under idling starts to spread over the sides, followed by recirculation of the fuel film along the sides of the manifold towards the carburettor. The reason for the recirculation is as follows: at low throttle openings, the air fuel mixture comes out of the carburettor as a jet from a small opening below the slider valve (throttle valve). This high speed jet causes a low pressure zone above the jet due to entrainment of air, and hence causes a recirculation of the fuel film as well as charge towards the carburettor. As the throttle is opened further, the film gets distributed all throughout the manifold inner walls, rather than staying just at bottom like in the idling case. Visualization experiments were performed at different engine speed at three throttle positions. From a qualitative visualization standpoint, the nature of the fuel transport is similar at all speeds. As the throttle is increased, the fuel film which is initially found to spread along the side walls at an angle at low throttle is observed to flow horizontally at high throttle. This is primarily due to the nature of the air flow while the throttle is being opened.

The results obtained through these visualization studies show a clear picture of fuel film transport under idling and load conditions, but the results are qualitative. In order to obtain a quantitative value of the thickness of the fuel film, a separate set of experiments were performed 

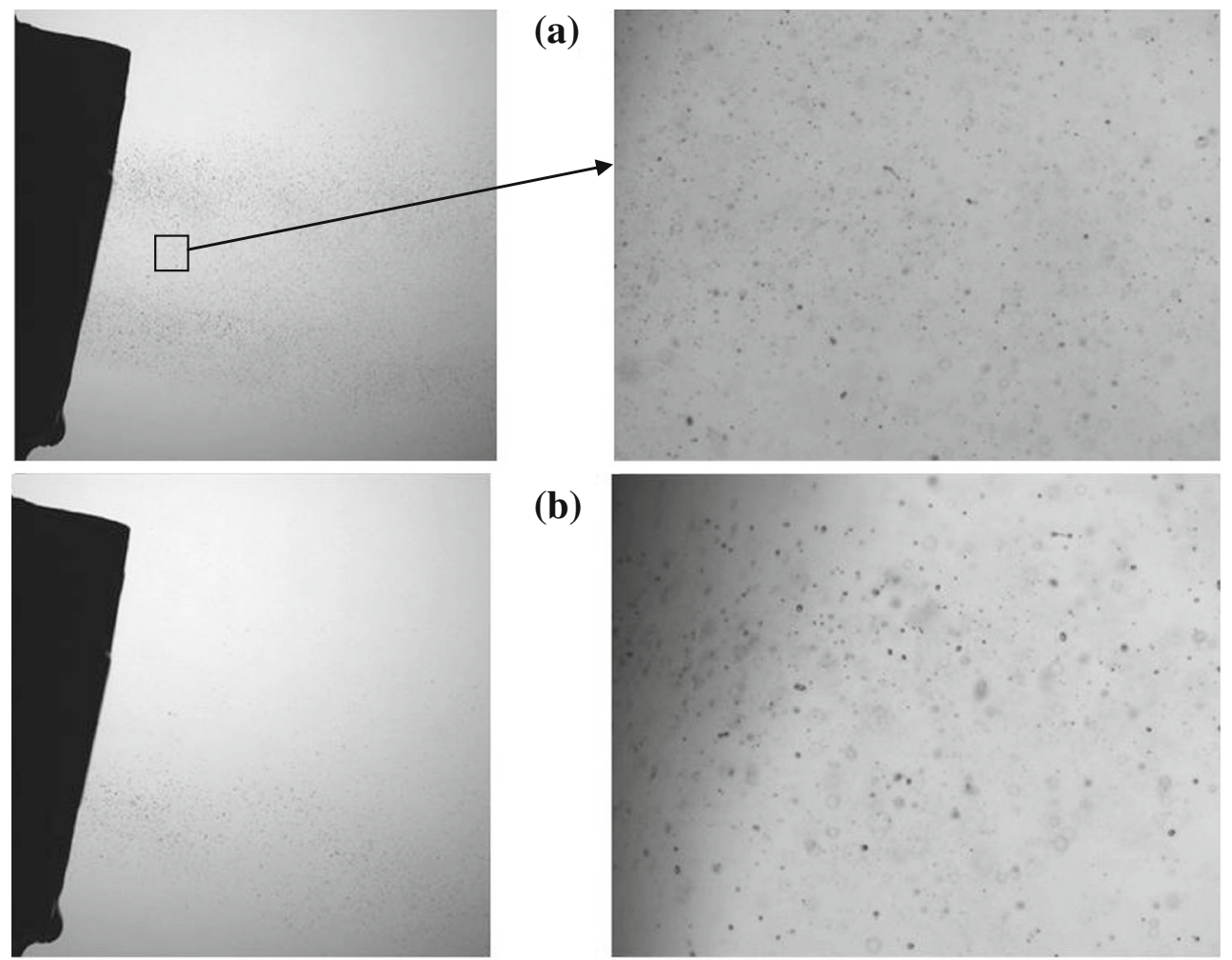

(b)

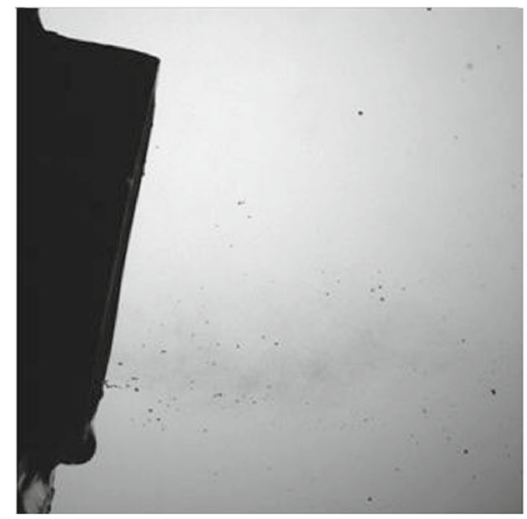

(c)
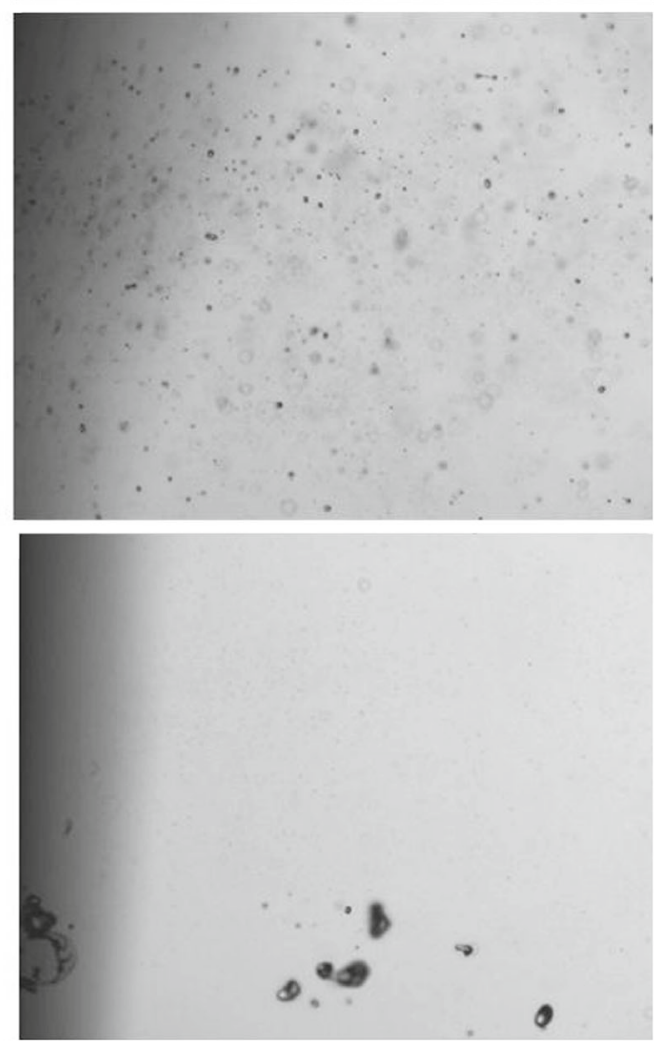

Figure 10. State of the charge exiting the carburettor at (a) Full throttle, (b) Half Throttle and (c) Idling conditions under steady pressure difference across the carburettor. The images on the right are typical magnified views of a small region spanning $5 \mathrm{~mm} \times 4 \mathrm{~mm}$ near the exit of the carburettor.

using the Planar Laser Induced Fluorescence (PLIF) technique. For these experiments, a square manifold was used with the optical setup as explained earlier. The results of the film thickness measurement have shown a maximum film thickness under idling of around $1 \mathrm{~mm}$ as shown in figure 8. It shows a typical PLIF image captured with a CCD camera provided with a narrow band filter. The background was subtracted from the images. The presence of fluorescence intensity now indicates the presence of a film. At every location along the length, the number of 


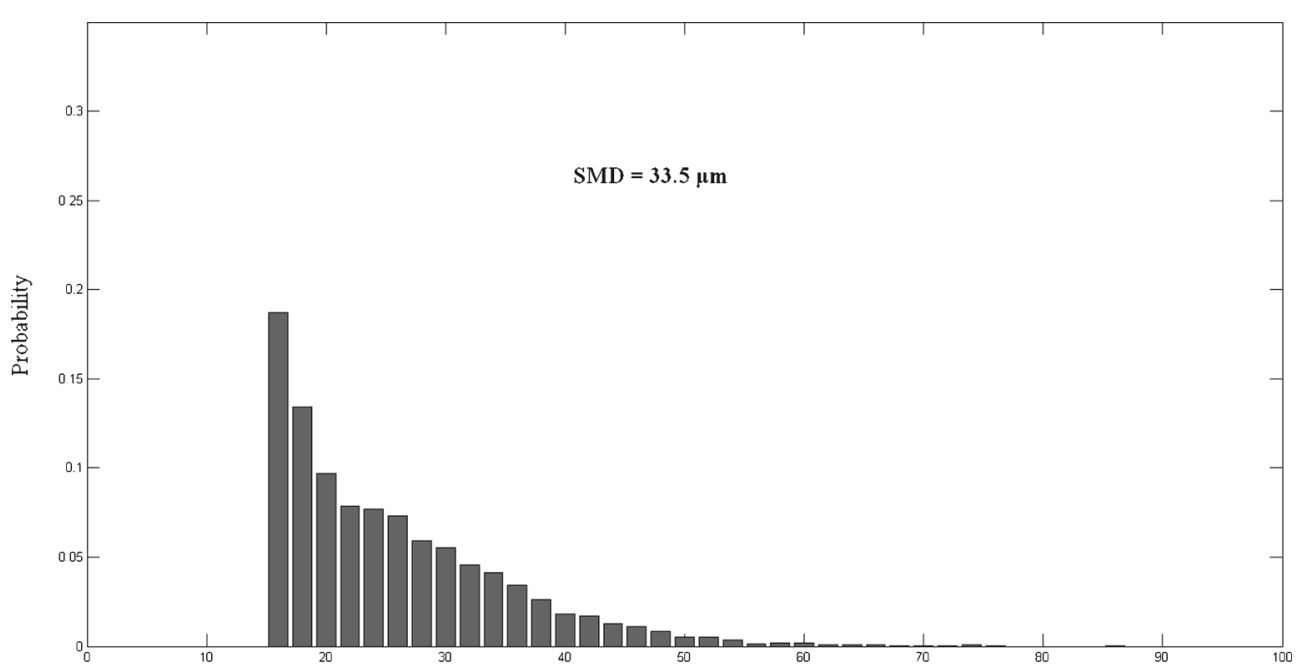

(a)

diameter $(\mu \mathrm{m})$

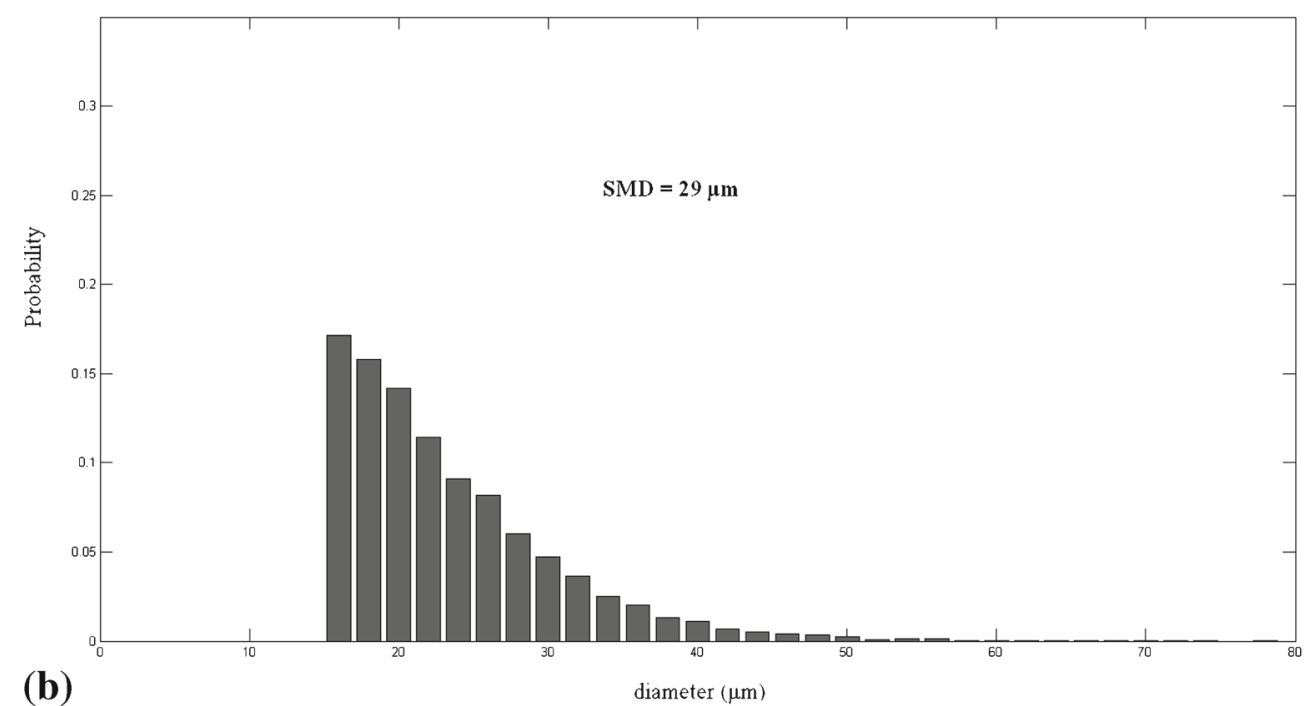

Figure 11. Droplet size distribution at (a) Half-throttle and (b) Full-throttle.

pixels in the direction perpendicular to the wall with intensities greater than a predefined threshold value was recorded as the film thickness. Similarly, film thickness measurements were also performed at different load conditions, the results of which are shown in figure 9. It is observed that under idling condition, the film thickness is highest, with films of the order of $1 \mathrm{~mm}$. Then as the engine is throttled, initially at low speed and low load, the film thickness is very low; of the order of $0.1 \mathrm{~mm}$. As the throttle is further opened, the film thickness increases to a maximum of $0.4 \mathrm{~mm}$ at high speed high load cases. One possible explanation for this variation could be that as the throttle is opened at low load and low speed condition (10 to $15 \%$ throttle opening), the fuel film present at the bottom wall under idling condition gets spread throughout the manifold cross section, thus decreasing the film thickness. As the throttle is further opened for mid 


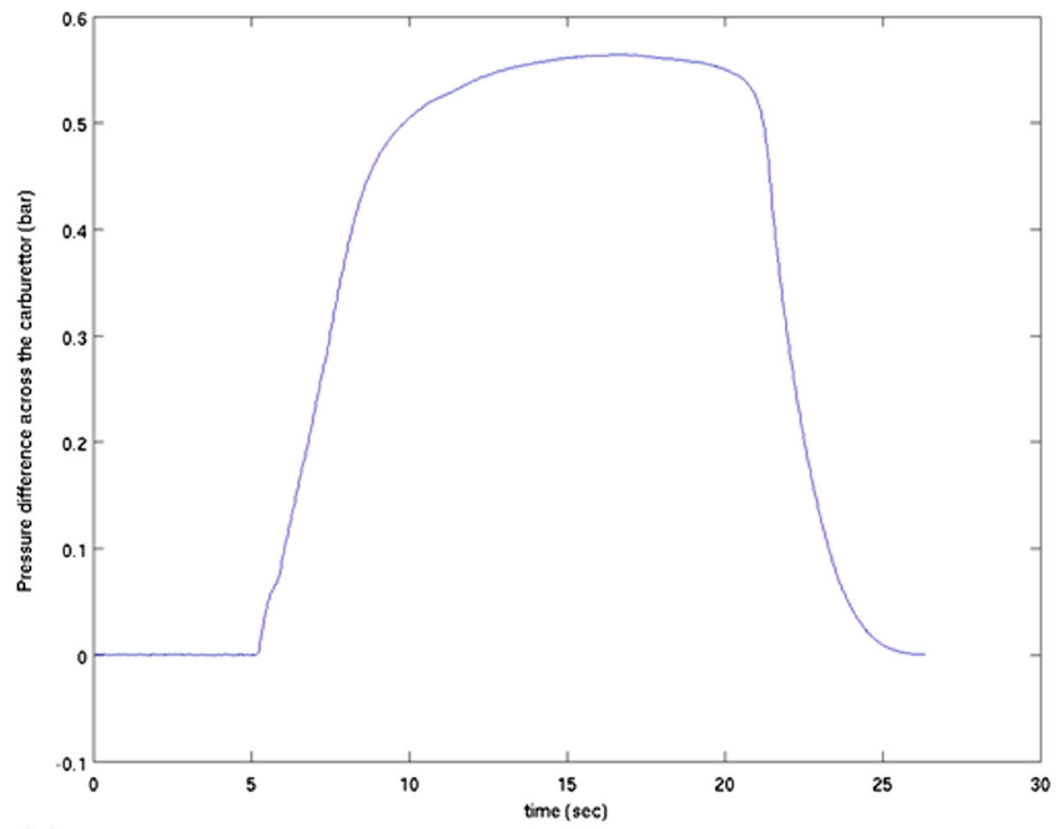

(a)

Idling

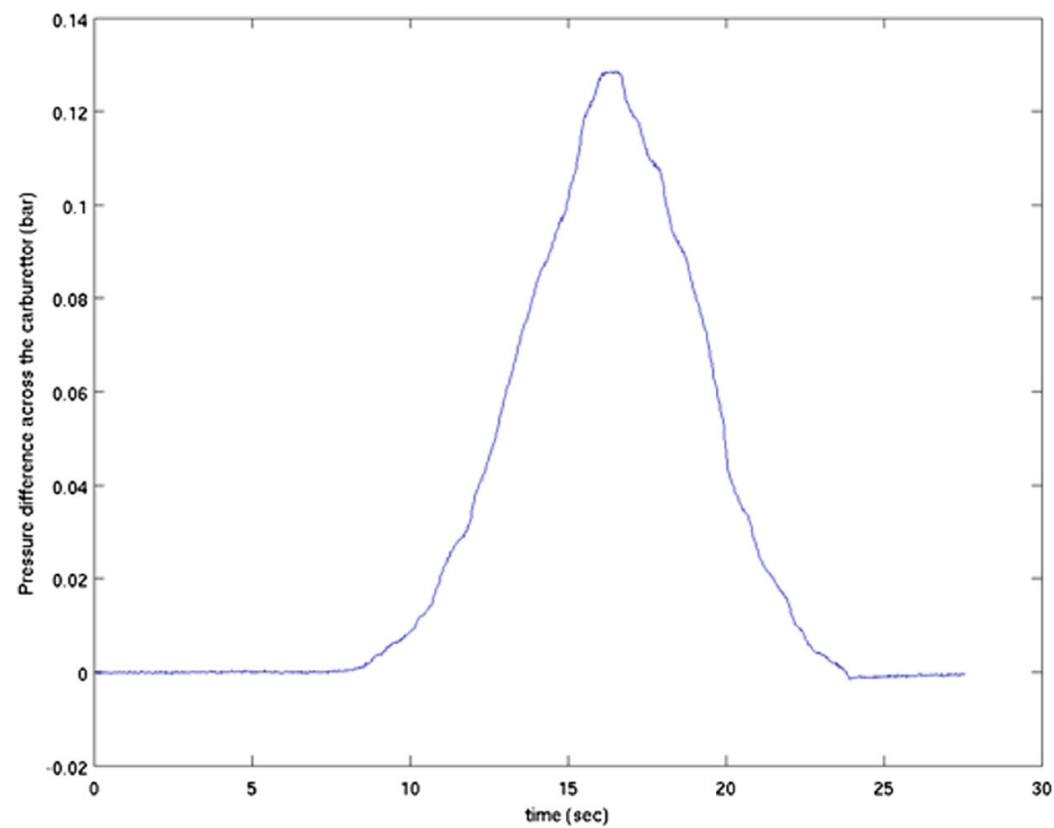

(b)

Full throttle

Figure 12. Pressure difference measured across the carburettor during (a) Idling throttle and (b) Full throttle position. 

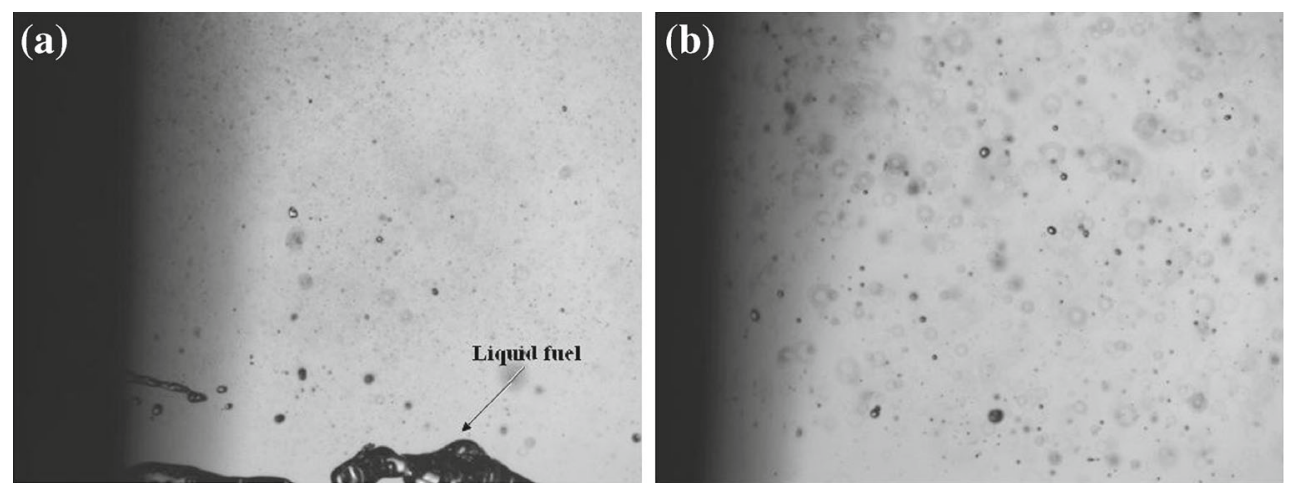

Figure 13. State of the charge exiting the carburettor at (a) Idling, (b) Full throttle under unsteady pressure variation. Each image spans a region of $5 \mathrm{~mm} \times 4 \mathrm{~mm}$ at the exit of the carburettor.

and high load cases, the other main metering circuit starts operating in the carburettor increasing the amount of fuel exiting the carburettor and consequently, the film thickness increases.

In order to further understand the state of charge exiting the carburettor, droplet sizing was conducted using the PDIA technique. Due to difficulty in ensuring good optical access with manifold walls getting wetted with fuel, these tests were performed in a stand-alone carburettor rig under steady state operation, where good optical access was ensured. Values of pressure difference across the carburettor under idling as well as load conditions in the engine were maintained across the carburettor in this steady-state test. The visualization results of the steady state tests for full throttle, half throttle and idling cases are shown in figure 10. In this figure, the visualization of the carburettor exit flows at steady state with normal and magnified views is obtained using the long distance microscope. A pressure difference of 0.08 bar across the carburettor was applied at both full and half load, and 0.55 bar under idling. From figure 11, it can be observed that the SMD of the droplets at full and half throttle is similar, and in the range of $30 \mu \mathrm{m}$, with a similar droplet size distribution. Under steady-state idling conditions, the charge exiting the carburettor is primarily in two states - a cloud of very small droplets (less than $10 \mu \mathrm{m}$ ) and large droplets or ligaments exiting out from the bottom surface of the carburettor as shown in the figure 10(c). A transient test was also performed where the pressure difference across the carburettor was varied. The experimental setup for the transient pressure test is mostly similar to that for the steady state test of the carburettor. For the transient test, the pressure upstream of the carburettor was varied using a valve which was present in the pipe ahead of the carburettor. The flow exits into atmospheric conditions. The pressure was varied slowly (as compared to variations in an actual engine). The objective of this experiment was to obtain a qualitative understanding of the effect of an unsteady pressure drop on the fuel delivery through the carburettor. The value of pressure difference measured across the carburettor during the idling throttle and full throttle tests is shown in figure 12.

Under unsteady carburettor functioning, however, there are larger droplets also observed at lower pressure values, as shown in figure 13. The droplets sizes under unsteady pressure fluctuation vary from larger size droplets (at low pressure) to smaller size droplets (at higher pressure) and then again become large as the pressure reduces. Under idling conditions, some large ligaments of the fuel are also observed exiting the carburettor, which forms the fuel film. Thus, it can be concluded from the visualization that under idling, the fuel film observed is possibly forming inside the carburettor at the edge of the slider valve and comes out in the form of large 
ligaments of liquid fuel. Variations in pressure would lead to large droplets and ligaments under unsteady engine conditions. Under high load conditions, the fuel film is being formed largely because of the fuel droplets striking the manifold walls. A few ligaments are also found to exit the carburettor under wide open throttle conditions.

\subsection{Cold-start emission studies}

As discussed earlier, there lies an ambiguity on the effect of these fuel films over hydrocarbon emissions in the literature. There is a need to have a better understanding of the cold start phenomena. Thus, after studying the nature of the fuel film transport inside the inlet manifold and its formation by studying the state of the charge exiting the carburettor, the important question of whether these films have any effect on $\mathrm{HC}$ emissions was also studied. For this, cold start idling emission tests are performed after every $12 \mathrm{~h}$ of soak time, as specified in many test protocols. For emission testing, a Delta $1600 \mathrm{~L}$ electro-chemical sensor based exhaust gas analyser with a RS 232 interface is used. In order to make sure that there is no influence of any prior engine runs, the exhaust port is purged before each run. Figure 14 shows a typical HC variation observed in various tests taken after a soak period of $12 \mathrm{~h}$ under idling condition. The $\mathrm{HC}$ emission curves starts with a peak (local maxima) followed by a dip (local minima) and it then increases and stabilizes at some intermediate value. The period at the beginning at which the emission reaches the peak and the local minima, is around $50 \mathrm{sec}$. The peak value at engine startup is observed not only at cold start conditions, but also under warmed-up conditions. This could be attributed to the transient operation involved at startup which causes incomplete combustion due to the lower

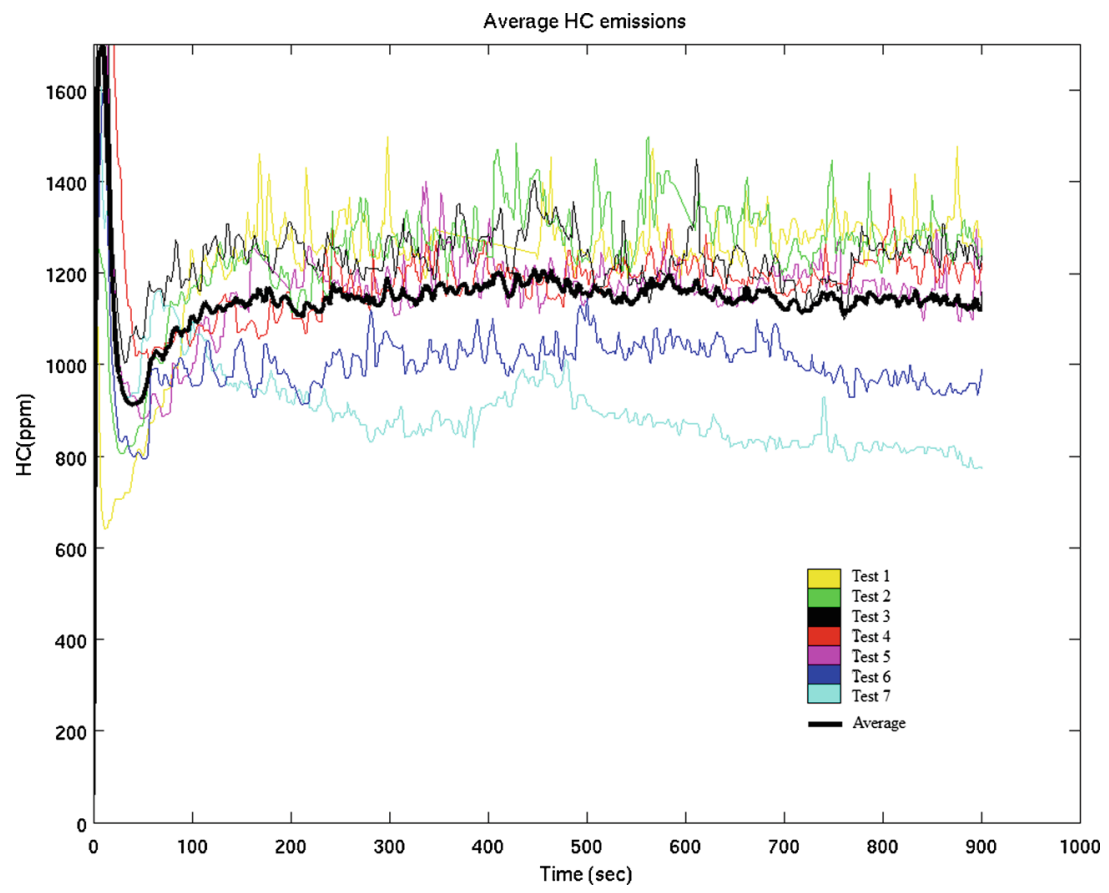

Figure 14. Unburned $\mathrm{HC}$ emissions under cold start idling conditions on different days. The black colour curve shows the average variation. 

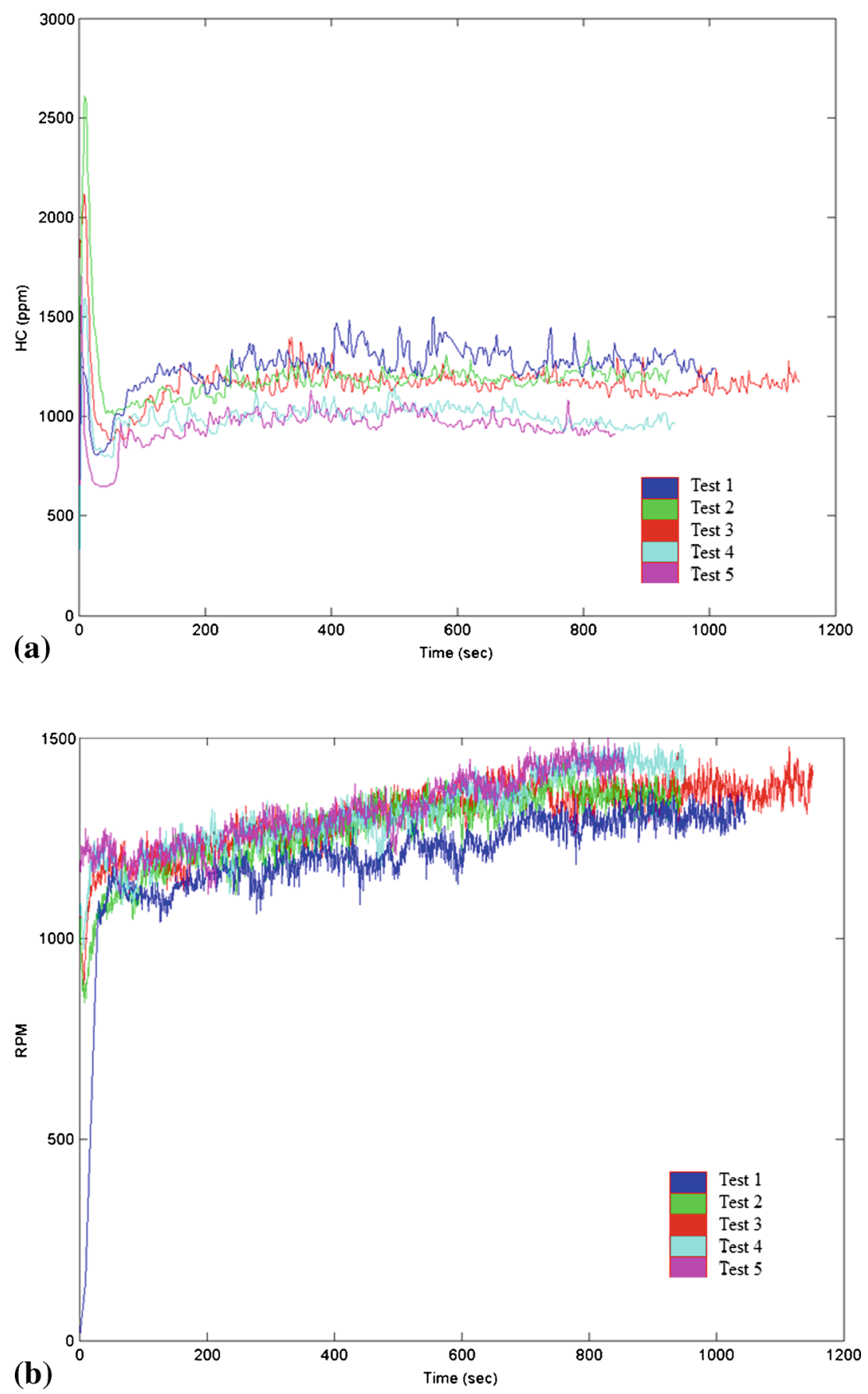

Figure 15. HC emission variation for unheated case as a function of engine speed. 
speeds and the consequent high HC emissions. It can also be concluded that though the emission curves follow the same trend, they vary largely in magnitude from day-to-day, as also observed by Salazar \& Ghandhi (2006). The day-to-day variation in HC emissions was observed to be in the range of 900-1200 ppm. To understand the reason for this variation, the engine speeds were also recorded and the correlation is shown in figure 15. It is observed that the HC emissions have a strong correlation with engine speed, varying inversely with engine speed. Also, with day-today variation in engine idling speed, the air-fuel ratio is found to become leaner as the engine speed increases. As the engine idling speed increases, the amount of air entering the engine increases, which causes the mixture to become leaner. Due to larger air flow over the fuel film inside the manifold, there may be increased shearing of the fuel film, which may lead to smaller droplets and hence more efficient combustion. This could explain the lowering of $\mathrm{HC}$ emissions.

A manifold heating strategy was then utilized to vaporize the film and to study its effect on $\mathrm{HC}$ emissions. The manifold was heated with a circumferential heating element from the outside. The heating was performed for a period of $240 \mathrm{sec}$. The location for heating was based on the fuel film visualization results under idling condition which showed the presence of a large amount of fuel film near the carburettor end. The engine was started after the manifold reaches certain preheated temperature. It was observed that there was a large day-to-day variation in the $\mathrm{HC}$ emission data in the heated cases also. Since a strong correlation was observed between the $\mathrm{HC}$ emissions and engine speed, the data for the heated and unheated cases were compared for cases where the engine speeds were similar, the results of which are shown in figure 16 . The data shown in figure 16 was obtained by averaging 7 sets of data each of which corresponds to experiments performed on different days, for the unheated and heated cases. Figure 16 shows that heating the manifold leads to a consistent reduction in $\mathrm{HC}$ emissions. It is also observed

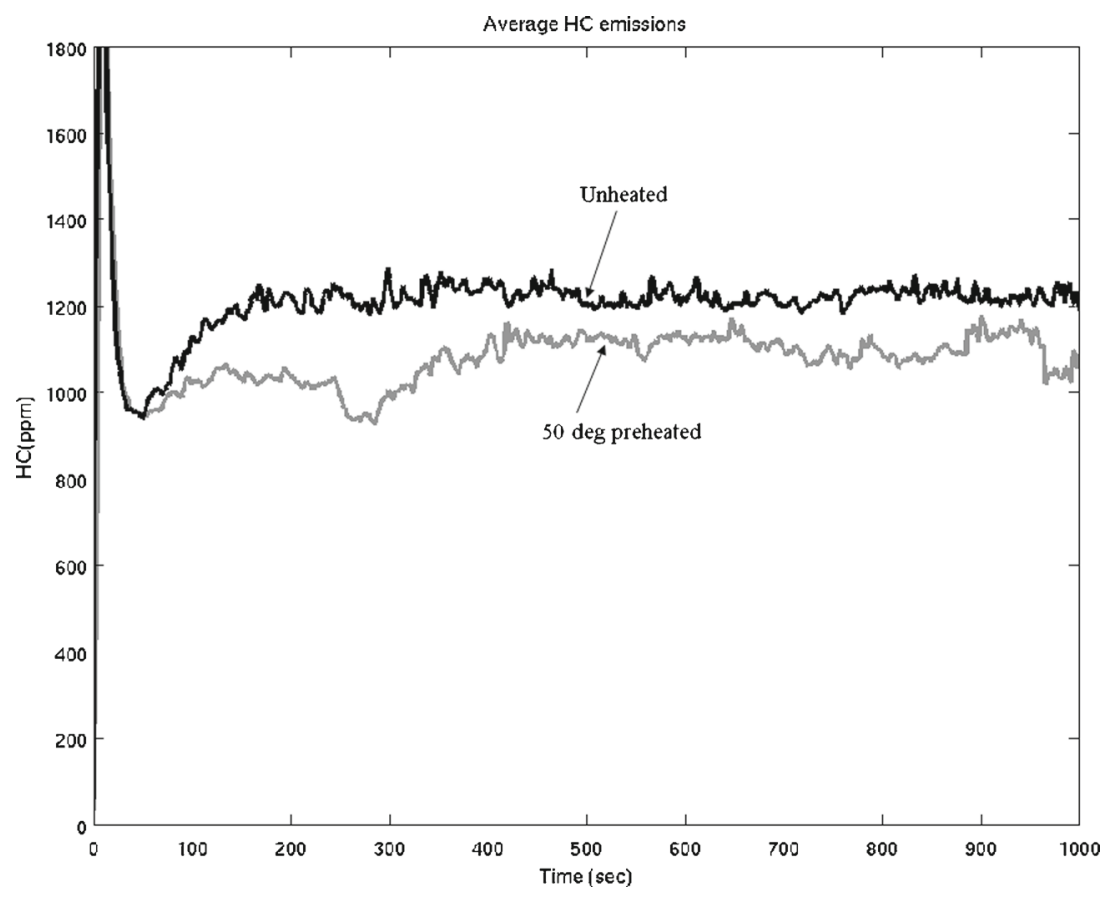

Figure 16. HC emission variation under cold start idling for unheated and heated cases. 

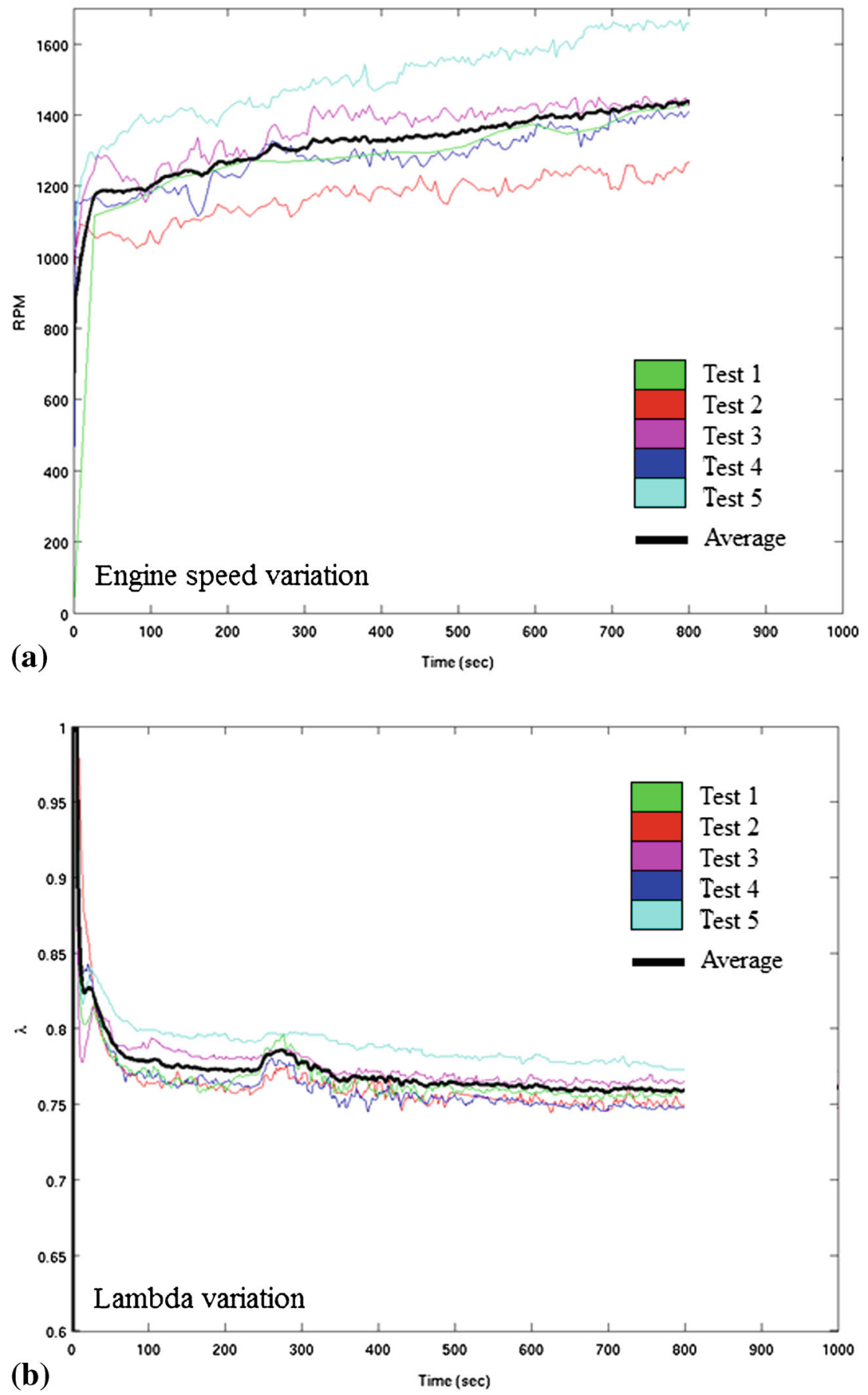

Figure 17. Lambda $(\lambda)$ variations at $35^{\circ} \mathrm{C}$ preheated case for different days with the engine speed variation with the corresponding colours. 
HC variation at different Jet numbers for different RPM and Throttle positions

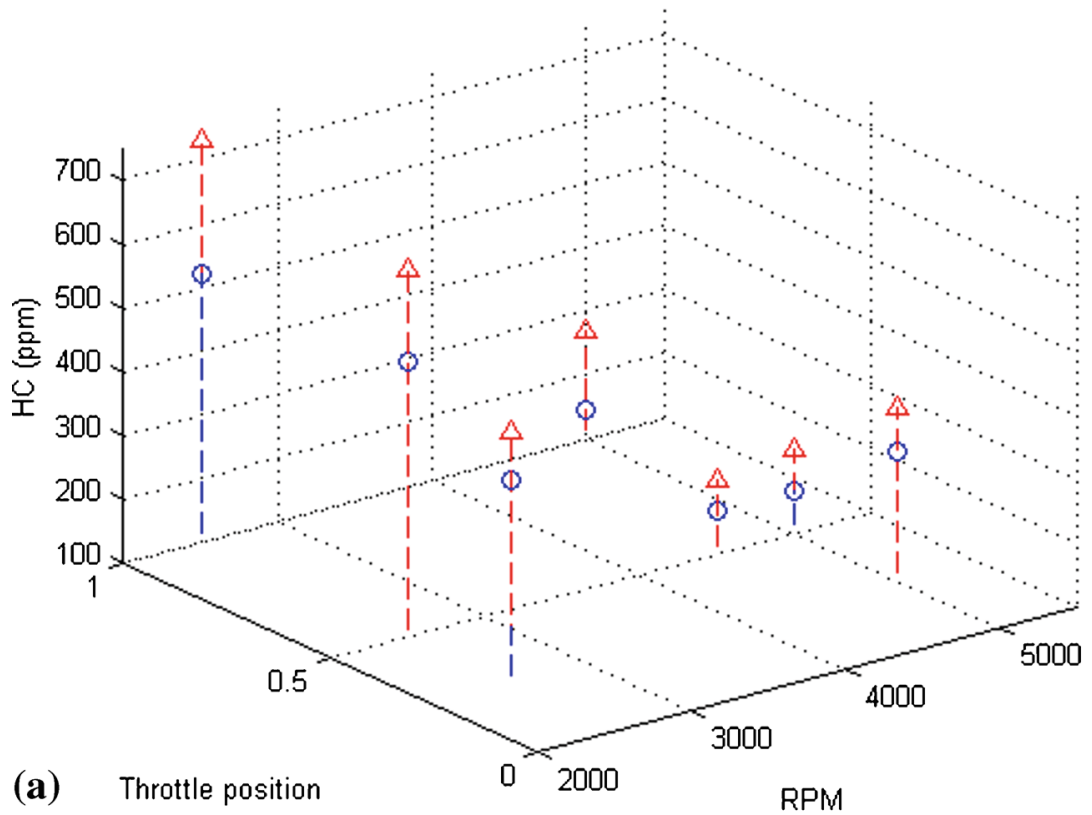

BSFC variation at different Jet numbers for different RPM and Throttle positions

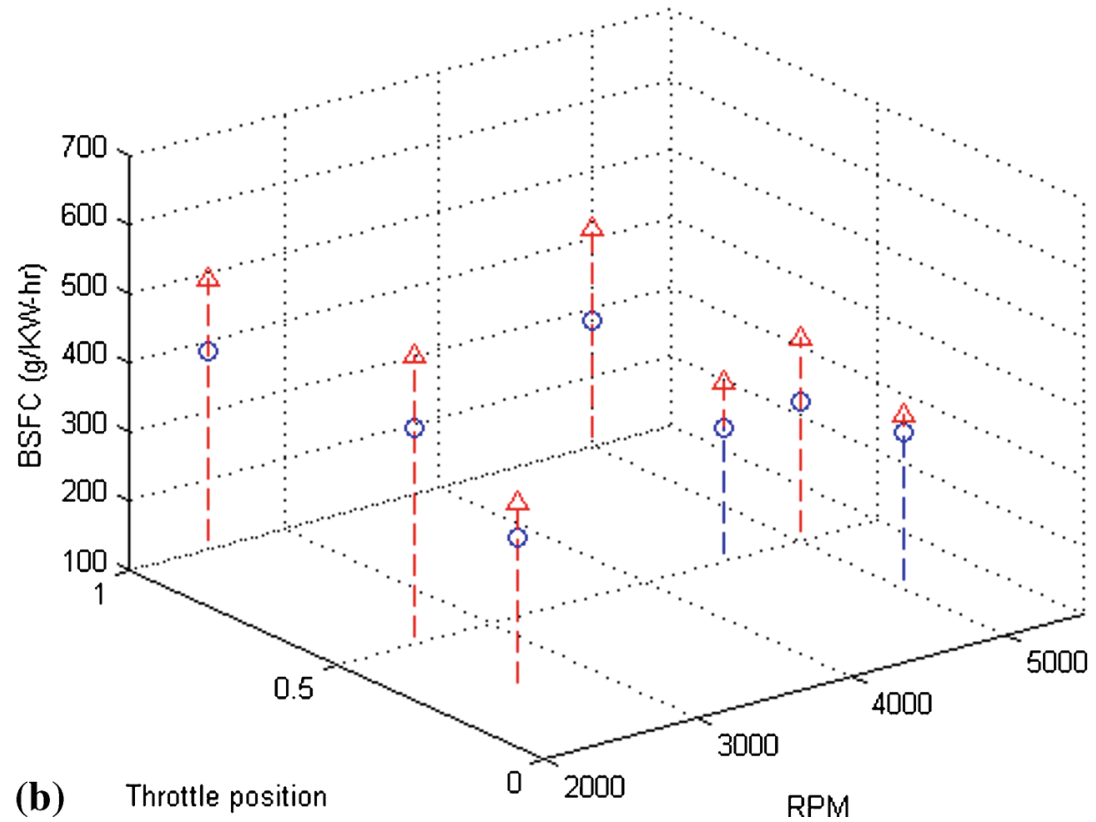

Figure 18. Comparison of (a) HC emissions and (b) Brake specific fuel consumption for Jet I (circle) and Jet II (triangle) nozzle diameter cases for various load and speed combinations. The vertical lines show the position on the $\mathrm{x}-\mathrm{y}$ plane. 
from figure 16 that for the preheated case, the HC emission shows a momentary drop when the manifold heating is stopped at $t=240 \mathrm{sec}$. Since the manifold is initially heated, wall films are not initially present and any droplets impinging on the walls evaporate and the vapour reaches the engine. However, when the heater is switched off, a fuel film starts to form over the manifold walls, which momentarily reduces the amount of fuel going inside the engine. This causes the mixture entering the engine to become lean and is reflected as a reduction in HC emissions. Figure 17 gives more insight into the effect of variation in lambda $(\lambda)$ of the air-fuel mixture on $\mathrm{HC}$ emission. It shows the variation of $\lambda$ with engine speed for the $35^{\circ} \mathrm{C}$ preheated case on different days. At the time the heater is switched off (after $240 \mathrm{sec}$ from the starting of the engine), the $\lambda$ value shows a sudden jump indicating that the mixture becomes lean, and then settles down after a period of 60-100 sec. This leads to a dip in the HC emission as observed earlier in figure 16. During this period, there is no significant change or jump in the engine speed values (figure 17a), which indicates that the only reason the mixture is becoming lean is due to a formation of fuel film, i.e., a part of the fuel ends up forming the film. This is how one of the physical effects concerning fuel transport is affecting the $\mathrm{HC}$ emissions. The second conclusion that can be drawn by comparing the day-to-day engine speed variation with the corresponding variation in $\lambda$ values is that as the engine speed increases, the $\lambda$ value increases, i.e., the mixture becomes lean. The reason is that the amount of air entering the engine is increased compared to the amount of fuel. Thus, this further explains why the cold start idling $\mathrm{HC}$ emission has an inverse relationship with the engine idling speed.

For easy starting of the engine at cold conditions, the mixture is currently maintained rich so that even after fuel film formation, a sufficient quantity of fuel exiting the carburettor reaches the engine in the intake stroke. The above results show that by vaporizing the fuel present in the form of film at idling, overall lower fuel consumption and reduced emissions can be achieved. The effect of manifold heating was studied under loading cases as well. However, the heating strategy did not show any consistent reduction in emissions under conditions of load. One possible reason for this is that the amount of fuel in the form of film is small compared to the total amount of fuel entering the engine. Hence, for the loading case, a different strategy is required. It was decided to evaluate a strategy involving reducing the main nozzle diameter keeping the carburettor idling circuit intact. For this, two nozzles were studied, i.e., Jet I with a diameter of $782 \mu \mathrm{m}$ and Jet II with a diameter of $667 \mu \mathrm{m}$. The manifold temperature values remain almost constant (except for full throttle) within a range of $40-45^{\circ} \mathrm{C}$. The air-cooled engine was cooled using a blower at non-idling conditions. The $\mathrm{HC}$ emissions and BSFC values for the two jets were compared at similar load points. The results shown in figure 18 indicate that by regulating the nozzle diameter, HC emission reduction as well as improvement in Brake Specific Fuel Consumption (BSFC) is possible. A reduction from 15 to $46 \%$ is observed in cold start $\mathrm{HC}$ emissions with 13 to $32 \%$ improvement in BSFC values. The other important finding from the experiment is that the percentage HC emission reduction increases with the RPM and also with throttle position. Thus, this work shows that for such small carburetted engines, there is a clear need for regulating the amount of fuel entering the engine under loading as well as for idling cases.

\section{Conclusions}

The present study involves the study of fuel film transport in the intake manifold of a small, carburetted engine and its effect on HC emissions under cold start conditions. Specifically, diagnostic techniques such as backlit visualization, PLIF and PDIA are used to qualitatively study the fuel film dynamics, and quantitatively to measure the fuel film thickness in a transparent 
section of the manifold and droplet sizes at the exit of the carburettor. Under cold start idling conditions, the fuel film is mostly observed at the bottom wall of the manifold. As the carburettor is throttled, the fuel film gets distributed all throughout the manifold cross-section. PLIF measurements have shown that under idling conditions, the fuel film thickness measured is of the order of $1 \mathrm{~mm}$. At low-speed, low-load case, the fuel film spreads throughout the manifold cross section and shows a minimum thickness of $0.1 \mathrm{~mm}$. As the speed and load is increased, the fuel film thickness increases to around $0.4 \mathrm{~mm}$. Experiments in a steady-state carburettor rig have shown that under idling, the fuel exiting the carburettor is mostly in two regimes - a cloud of very small droplets (less than $10 \mu \mathrm{m}$ in size) and large droplets with ligaments. At half and full throttle loading conditions, the SMD is in the range of $30 \mu \mathrm{m}$. Based on the understanding obtained from these studies, the formation of $\mathrm{HC}$ emissions under cold start is also studied. Detailed cold start emission studies have shown that the day-to-day variations in HC emissions under cold start idling were due to the variation in engine speed and have an inverse relation with engine idling speed. A manifold heating strategy has shown a consistent reduction in HC emissions under idling, however was ineffective under load. A strategy of reducing the diameter of the inlet nozzle of the main jet of carburettor was observed to reduce HC emissions and also increase fuel efficiency. Overall, this work shows that a combination of a manifold heating strategy under cold start conditions along with an electronic carburettor to control fuel flow under idling and load has the potential to reduce HC emissions and increase fuel efficiency for small carburetted engines.

\section{Notations}

BSFC Brake Specific Fuel Consumption
CCD Charge Coupled Device
DC Direct Current
FHM Full width half maximum
EVC Exhaust Valve Closure
EVO Exhaust Valve Open
HC Hydrocarbon
IVC Inlet Valve Closure
IVO Inlet Valve Open
PLIF Planar Laser Induced Fluorescence
RPM Revolution per minute
SMD Sauter Mean Diameter
SORE Small Off-road Engines
TDC Top Dead Center

\section{References}

Arias D A and Shedd T A 2004 Numerical and experimental study of fuel and air flow in carburetors for small engines, SAE Technical Paper 2004-32-0053

Felton P G, Kyritsis D C and Fulcher S K 1995 LIF visualization of liquid fuel in the intake manifold during cold start. SAE Transactions 952464: 2278-2286

Finlay L C, McMillan T, Bannell J L K and Nightingale C 1984 The measurements of the sizes of droplets leaving the throttle plate of the air valve carburettor. J. Phys. Appl. Phys., 18: 1213-1222 
Hamid B S and Walter W Y 1985 Deposition of fuel droplets in horizontal intake manifolds and the behavior of fuel film flow on its walls. SAE Transactions 2 125-133

Harrington D L and Bolt J A 1970 Analysis and Digital Simulation of Carburettor Metering. SAE Technical Paper 700082

Hasson D A and Flint W L 1989 An investigation of the liquid petrol wall film in the manifold of a carburetted spark ignition engine: Effect of carburettor and manifold geometry on wall film quantities, engine performance and emissions. Proc. Institution Mech. Eng., 203, 77-89

Itano E 1996 Characterization of carburettor exit flow. Thesis for Master of Science, Mechanical Engg., University of Wisconsin-Madison

Li J and Collings N 1999 A semi-empirical model of fuel transport in intake manifolds of SI engines and its application in transient conditions, SAE Technical Paper 1999-01-1314

Oya T 1971 Upward liquid flow in a small tube into which air streams. Bull. JSME, 14(78): 1320-1339

Salazar V M and Ghandhi J B 2006 Liquid fuel effects on the unburned hydrocarbon emissions of a small engine. SAE Technical Paper 2006-32-0033

Tanaka M and Durbin E 1977 Transient response of a carburetor engine, SAE Technical Paper 770046 